\title{
POLA MAKAN TERHADAP KEJADIAN OBESITAS PADA ANAK
}

\author{
Sriwahyuni $^{1}$, Junaidin ${ }^{2}$, Noyumala ${ }^{3}$, Alfiah.A ${ }^{4}$, Vitarianti Tangkelayuk ${ }^{5}$ \\ ${ }^{1)}$ Program Studi Profesi Ners STIKes Nani Hasanuddin Makassar \\ 2) Program Studi Profesi Ners, STIKes Amanah, Makassar, Indonesia \\ ${ }^{3)}$ Program Studi Profesi Ners, STIKes Gunung Sari, Makassar \\ 4) Program Studi DIII Keperawatan, STIKes Nani Hasanuddin Makassar \\ ${ }^{5)}$ Program Studi S1 Keperawatan, STIKes Nani Hasanuddin Makassar \\ sriwahyunicallista@gmail.com
}

\begin{abstract}
ABSTRAK
Obesitas merupakan masalah utama bagi tubuh karena efeknya akan membuat tubuh menjadi lambat bergerak. Penyebab obesitas bersifat multifaktorial. Peningkatan konsumsi makanan cepat saji (fastfood), terutama di kota besar, bergeser dari pola makan tradisional ke pola makan barat (terutama dalam bentukfastfood). Prevalensi gizi lebih pada anak usia sekolah dengan jenis kelamin laki-laki adalah 9,5\% sedangkan perempuan adalah $6,4 \%$. Prevalensi status gizi lebih nasional pada anak sekolah (6-12 tahun) yaitu 9,2\%. Pada tahun 2013 prevalensi gizi lebih juga mengalami peningkatan menjadi 18,8\%. Tujuan penelitian ini untuk mengetahui pola makan fast food terhadap kejadian obesitas pada anak di SD Frater Bakti Luhur Makassar. Metode penelitian ini menggunakan deskritif analitik dengan pendekatan cross-sectional. Populasi berjumlah 30 orang. Pengambilan sampel dengan teknik total sampling. Pengumpulan data menggunakan kuesioner dan lembar observasi (pengukuran antropometri) kemudian dianalisis dengan uji chi-square $(\mathrm{p}<0,05)$. Didapatkan hasil analisis bivariate menunjukkan adanya hubungan pola makan fast food terhadap kejadian obesitas pada anak dengan nilai $\mathrm{p}=0,031<\alpha=0,05$. Kesimpulan dalam penelitian ini adalah pola makan fast food dapat meningkatkan berat badan jika dikomsumsi lebih dari 2 kali seminggu. Saran agar memperhatikan pola makan fast food yang dikomsumsi oleh anak yang dapat menyebabkan terjadinya obesitas.
\end{abstract}

Kata kunci : anak, pola makan, obesitas

\section{Abstract}

Obesity is a major problem for the body because its effect will make the body move slowly. The causes of obesity are multifactorial. The increase in consumption offast food, especially in big cities, has shifted from a traditional diet to a western diet (especially in the form of fast food). The prevalence of over nutrition among schoolage children for male is $9.5 \%$, while the one for female is $6.4 \%$. The prevalence of national over nutrition status in school children (6-12 years) is 9.2\%. In 2013 the prevalence of over nutrition also increased to $18.8 \%$. The aim of this study is to determine the fast-food eating pattern on the occurrence of obesity in children in Primary School of Frater Bakti Luhur, Makassar. The research method uses descriptive analytic with a cross sectional approach. The population consists of 30 peopleandthe sample wasdeterminedusingtotal sampling technique. Data collection used questionnaires and observation sheets (anthropometric measurements) and they were then analyzed using chi test -square ( $p<0.05$. The results of bivariate analysis show a relationship between fast food diet and the occurrence of obesity in children with a value of $p=0.031<\alpha=0.05$. The conclusion in this study is that a fast-food diet can increase body weight if it is consumed more than two times a week. It is suggested to pay attention to the fast-food diet consumed by children which can cause obesity.

Keywords: child, diet, obesity 


\section{PENDAHULUAN}

Obesitas merupakan penyakit metabolik yang ditandai dengan akumulasi lemak yang berlebihan. Aktivitas fisik yang rendah menjadi salah satu penyebab terjadinya obesitas. Keadaan obesitas dapat diukur dengan menggunakan persentase lemak tubuh yang didefinisikan sebagai proporsi dari massa lemak tubuh seseorang (Effendy et al., 2018). Obesitas dikatakan sebagai suatu kondisi kelebihan kadar lemak dalam tubuh seseorang yang tertimbun dalam jaringan subkutan yang dapat mengakibatkan munculnya penyakit kronis anak dengan obesitas adalah salah satu tantangan kesehatan masyarakat global yang paling serius dari abad ke-21 yang mempengaruhi setiap negara di dunia, Saat ini masalah obesitas bahkan sudah banyak dialami oleh anak-anak salah satu tindakan utama untuk menangani obesitas pada usia anak adalah melalui orang terdekatnya yaitu keluarga (Triana et al., 2020).

Menurut Sargowo \& Andarini, (2011) Overweight dan obesitas menjadi masalah utama bagi tubuh karena efeknya akan membuat tubuh menjadi lambat bergerak. Tubuh yang tidak bergerak untuk mengolah lemak menjadi karbohidrat akan menyebabkan terjadinya penimbunan lemak terus-menerus sehingga mempengaruhi kesehatan, baik secara fisik seperti memiliki banyak lipatan pada perut, pinggang, dan lengan maupun secara psikologis seperti timbulnya rasa malu dan kurang percaya diri.(Triana et al., 2020)

Berdasarkan hasil Riset Kesehatan Dasar RISKESDAS (2013), diketahui bahwa prevalensi obesitas di Indonesia pada kelompok usia 5-12 tahun sebesar 18,8\% (10,8\% kegemukan dan $8,0 \%$ obesitas) dan pada kelompok usia 1315 tahun sebesar 10,8\% (8,3\% kegemukan dan 2,5\% obesitas), di Provinsi Bengkulu sendiri prevalensi untuk status gizi anak usia 5-12 tahun berdasarkan (IMT/U) yaitu sangat kurus 3,8\%, kurus 5,1\%, normal $66,5 \%$, gemuk $13,9 \%$ dan obesitas 10,7\% (Triana et al., 2020) Pada Negara Asia, prevalensi obesitas di Korea Selatan 20,5\% overweight dan $1,5 \%$ obesitas, Thailand $16 \%$ overweight dan $4 \%$ obesitas, di China $12 \%$ pada laki-laki overweight dan 14,4\% pada perempuan. Prevalensi anak obesitas berusia 6-12 tahun di Indonesia pada tahun 2010 cukup tinggi (9,2\%). Menurut data hasil Riskesdas 2013 di Sulawesi Selatan, prevalensi obesitas umum untuk lakilaki sebesar 18,5 \% dan perempuan 31,5\%, dan kota Makassar sebanyak 10,3\% obesitas (Ishak et al., 2019).

Overweight dan obesitas pada anak sampai saat ini masih menjadi masalah, dimana satu dari sepuluh anak di dunia ini mengalami obesitas. Populasi anak-anak yang kegemukan atau obesitas telah naik 10 kali lipat dalam empat dasawarsa terakhir. Overweight dan obesitas merupakan istilah yang digunakan dalam berat badan berlebih. Kejadian berat badan berlebih pada anak usia sekolah dipengaruhi beberapa faktor seperti faktor pola makan, aktivitas fisik, dan pola tidur (Irma rachmawati, 2018). Pola Tidur dini dikaitkan dengan peningkatan sekresi hormon pertumbuhan manusia (GH) melalui penghambatan muskarinik somatostatin, penekan GH (Jeremy D. Coplan, Susan I. Wolk, Raymond R. Goetz, Neal D. Ryan \& Ronald E. Dahl, J. John Mann, 2020). Faktor penyebab obesitas pada remaja bersifat multifaktorial. Peningkatan konsumsi makanan cepat saji (fast food), rendahnya aktivitas fisik, faktor genetik, pengaruh iklan, faktor psikologis, status sosial ekonomi, program diet, usia, dan jenis kelamin merupakan faktor-faktor yang berkontribusi pada perubahan keseimbangan energi dan berujung pada kejadian obesitas (Kurdanti et al., 2015). Pola makan, terutama di kota besar, bergeser dari pola makan tradisional ke pola makan barat (terutama dalam bentuk fast food) yang sering mutu gizinya tidak seimbang. Pola makan tersebut 
merupakan jenis-jenis makanan yang bermanfaat, akan tetapi secara potensial mudah menyebabkan kelebihan masukan kalori. Berbagai makanan yang tergolong fast food tersebut adalah kentang goreng, ayam goreng, hamburger, soft drink, pizza, hotdog, donat, dan lain-lain (Setyawati \& Rimawati, 2016)mempengaruhi tidak hanya negara maju tapi juga negara berkembang. Survei obesitas yang dilakukan akhir-akhir ini pada anak remaja siswa/siswi SLTP di Yogyakarta menunjukkan bahwa $7,8 \%$ remaja di perkotaan dan $2 \%$ remaja di daerah pedesaan mengalami obesitas. Pada tahun 2011 berdasarkan hasil penjaringan peserta didik TA 2011/2012 di Kota Semarang pada remaja usia 16 tahun dari 16.579 anak sebesar 3,71\% berstatus gizi lebih. Penelitian ini bertujuan mengetahui apakah ada hubungan antara serat dan fast food dengan gizi lebih. Penelitian ini dilakukan di Kota Semarang pada remaja sejumlah 65 orang. Variabel bebas penelitian ini adalah pola konsumsi fast food dan serat, sedangkan variabel terikatnya adalah status gizi. Analisis data yang digunakan adalah chi square. Hasilnya, 58,5\% responden mengalami malnutrisi yang terdiri dari underweight, overweight, obesitas I, dan obesitas II; sementara $41,5 \%$ responden berstatus gizi normal. Sehingga bisa dikatakan bahwa remaja bermasalah dengan status gizi. Konsumsi fast food ( $\mathrm{p}=0,21)$. Menurut Rossen LM, Rossen EA (2012) obesitas didefinisikan sebagai akumulasi lemak yang tidak normal atau berlebihan yang menimbulkan risiko kesehatan yaitu meningkatnya persentase lemak seseorang karena beberapa seperti kondisi medis, peningkatan hormon, kecanduan makanan yang menyebabkan ketidakseimbangan kalori yang berlebihan berasal_dari protein, lemak atau karbohidrat. Pola makan memainkan peran utama dalam asupan energi dan manajemen berat badan sehingga diperlukan asupan makanan bertepung (Karbohidrat) dan buah-buahan, sayuran, dan produk susu dalam jumlah yang sangat sedikit
(Balasooriya, 2016).

Faktor kecukupan gizi pada anak- anak, ditentukan oleh kecukupan konsumsi pangan, sedangkan pada masa tersebut anak cenderung lebih aktif untuk memilih sendiri makanan yang disukainya. Hal ini perlu diperhatikan, karena kebiasaan makanan yang biasa dikonsumsi sejak masa kanak-kanak akan membentuk pola kebiasaan makan selanjutnya, ada beragam faktor yang menjadi penyebab terjadinya perubahan konsumsi makanan pada anak $\mathrm{SD}$, yaitu tersedianya berbagai jenis pilihan makanan, pemahaman orang tua yang terbatas mengenai kualitas makanan yang dikonsumsi sehari-hari, ibu yang bekerja, dan pengaruh iklan (Rahmayanti \& F.D., 2017)sedangkan pada masa tersebut anak cenderung lebih aktif untuk memilih sendiri makanan yang disukainya. Pola konsumsi makanan pada anak sekolah dasar mengalami perubahan dari pola makanan tradisional ke pola makanan barat yang umumnya merupakan pola makanan yang tidak sehat karena memiliki kandungan gizi yang rendah tetapi tinggi kalori dan lemak. Tujuan penelitian ini adalah untuk menganalisis hubungan antara pola makan anak dengan status gizi anak usia 6-8 tahun di SD wilayah Kelurahan Cempaka. Jenis penelitian ini adalah penelitian non eksperimen dengan menggunakan rancangan penelitian cross sectional dengan teknik purposive sampling. Jumlah sampel sebanyak 30 ibu dan 30 anak. Instrumen penelitian yang digunakan adalah kuesioner pola makan anak yang diisi ibu dan timbangan berat badan serta pengukur tinggi badan anak. Analisis data menggunakan uji spearman rank. Hasil Penelitian sebagian besar anakmemiliki pola makan sedang sebanyak 24 $\operatorname{anak}(80 \%)$.

Berdasarkan data dari SD Frater Bakti Luhur Makassar diketahui jumlah siswa siswi keseluruhan kelas IV dan V sebanyak 278 orang terdiri dari masing-masing 4 kelas. Juga 
dilakukan survey singkat oleh peneliti di sekolah tersebut, peneliti menemukan beberapa siswa yang yang mengalami obesitas/ berat badan melebihi normal yaitu 30 orang, tingginya kejadian tersebut sehingga peneliti tertarik untuk melakukan penelitian tentang "Pola makan terhadap kejadian obesitas pada Anak di SD Frater Bakti Luhur Makassar”.

\section{METODOLOGI}

Penelitian ini menggunakan metode deskritif analitik dengan rancangan pendekatan cross-sectional study. Populasi dalam penelitian ini jumlah sampel merupakan total sampling adalah semua anak kelas 4 dan 5 yang berat badan lebih dari normal di SD Frater Bakti Luhur Makassar sebanyak 30 orang.

\section{Instrumen Penelitian}

Instrumen penelitian ini menggunakan Kuesioner, kuesioner belum pernah digunakan sebelumnya, tetapi sudah di uji nilai validitasnya yaitu R hitung > R tabel, R tabel yaitu 0 , 361. dengan variabel independen pola makan sebanyak 10 pernyataan, untuk variabel dependen obesitas menggunakan lembar observasi dengan mengukur antropometri untuk mendapatkan IMT. alat yang digunakan untuk antrpometri timbangan injak dan alat pengukur tinggi badan yaitu microtoice.

\section{Analisis Data}

Analisis univariat dikerjakan pada tiap variable hasil penelitian bertujuan untuk mengetahui gambaran frekuensi distribusi pada tiap variable dan analisis bivariate untuk mencari hubungan terhadap variabel pola makan anak dengan kejadian obesitas dengan menggunakan uji Chi-Square $\rho<\alpha=0,05$ untuk membandingkan frekuensi observasi dengan nilai frekuensi harapan sama.
HASIL

Tabel 1. Distribusi Frekuensi Berdasarkan

Karakteristik Demografi di SD Frater Bakti Luhur Makassar ( $\mathbf{N = 3 0 )}$

\begin{tabular}{lcc}
\hline Karakteristik & f & \% \\
\hline Umur & & \\
8 & 4 & 13,3 \\
9 & 10 & 33,3 \\
10 & 12 & 40,0 \\
11 & 4 & 13,3 \\
Jenis Kelamin & & \\
$\quad$ Laki-laki & 23 & 76,7 \\
$\quad$ Perempuan & 7 & 23,3 \\
Pekerjaan & & \\
$\quad$ PNS & 14 & 46,7 \\
$\quad$ Wiraswasta & 16 & 53,3 \\
Pendidikan & & \\
$\quad$ S1-S2 & 23 & 76,7 \\
$\quad$ SMA & 7 & 23,3 \\
\hline
\end{tabular}

Tabel. 2 Analisis Univariat hubungan pola makan dengan kejadian obesitas pada anak di SD Frater Bakti Luhur Makassar.

\begin{tabular}{lcc}
\hline Variabel & N & \% \\
\hline Pola makan & & \\
$\quad$ Sering & 23 & 76,7 \\
$\quad$ Jarang & 7 & 23,3 \\
Kejadian Obesitas & & \\
$\quad$ Obesitas & 26 & 86,7 \\
$\quad$ Overweight & 4 & 13,3 \\
\hline
\end{tabular}

Berdasarkan tabel 1 dari 30 anak yang memiliki umur 10 tahun berjumlah 12 responden (40,0\%), di ketahui responden jenis kelamin laki-laki sebanyak 23 responden (76,7\%), berdasarkan pekerjaan orangtua yang terbanyak yaitu wiraswasta dengan jumlah 16 responden $(53,3 \%)$, diketahui bahwa pendidikan orang tua anak yang paling terbanyak yaitu S1- S2 yaitu 23 responden dengan presentasi $(76,7 \%)$. pola makan dalam kategori jarang sebanyak 7 responden $(23,3 \%)$, kategori sering yaitu 23 
responden $(76,7 \%)$. diketahui bahwa kategori obesitas sebanyak 26 responden (86,7\%), sedangkan kategori overweight (13,3\%). Berdasarkan tabel 2, menunjukkan bahwa dari 30 orang orang sampel yang menjadi subjek penelitian, ada terdapat 7orang dengan (23,3 \%) yang pola makan fast food jarang, dari jumlah tersebut terdapat 4 orang $(13,3 \%)$ yang mengalami obesitas dan 3 orang $(10,0 \%)$ yang overweight, sedangkan pola makan kategori sering terdapat ada 23 orang (76,6\%), dimana 22 orang $(73,3 \%)$ yang obesitas dan 1 responden $(3,3 \%)$ yang overweight. Setelah dilakukan hasil uji statistik dengan chi-squere diperoleh nilai $p=0,031$ yang berarti $p<\alpha=0,05$ maka hipotesis nol ditolak dan hipotesis alternatif diterima maka ada hubungan pola makan dengan kejadian obesitas pada anak di SD Frater Bakti Luhur Makassar.

Tabel.3 Analisis bivariate hubungan pola makan dengan kejadian obesitas pada anak Di SD Frater Bakti Luhur Makassar

\begin{tabular}{|c|c|c|c|c|c|c|c|}
\hline \multirow{3}{*}{ Pola Makan } & \multicolumn{6}{|c|}{ Kejadian Obesitas } & \multirow{3}{*}{$\rho$-Value } \\
\hline & \multicolumn{2}{|c|}{ Obesitas } & \multicolumn{2}{|c|}{ Overweight } & \multicolumn{2}{|c|}{ Jumlah } & \\
\hline & $\mathbf{f}$ & $\%$ & $\mathbf{f}$ & $\%$ & $\mathbf{n}$ & $\%$ & \\
\hline Sering & 22 & 73,3 & 1 & 3,3 & 23 & 76,6 & \\
\hline Jarang & 4 & 13,3 & 3 & 10,0 & 7 & 23,3 & 0,031 \\
\hline Total & 26 & 86,7 & 4 & 13,3 & 30 & 100 & \\
\hline
\end{tabular}

Hubungan Pola Makan Dengan Kejadian Obesitas pada anak di SD Frater Bakti Luhur Makassar. Berdasarkan hasil penelitian ini didapatkan anak yang memiliki pola makan sering sebanyak 23 responden (76,6\%) dikarenakan anak senang dengan jenis makanan fast food sehingga pola makan fast food anak > 2x/minggu, hal ini dapat dilihat pada proses penelitian yang dilakukan terdapat beberapa jenis fast food yang dijual dikantin sekolah, selain itu sebagian besar anak menghabiskan banyak waktu di sekolah sehingga anak lebih sering berbelanja di kantin. Hal ini menjadi salah satu penyebab anak-anak sering mengonsumsi makanan fast food dari hasil observasi jenis fast food yang sering dikonsumsi anak pada saat jam istirahat yaitu bakso, nugget, eskriem, pop mie.

\section{PEMBAHASAN}

Hasil penelitian ini, menunjukkan bahwa bukan hanya disekolah, tetapi ketika anak di luar sekolah atau dirumah anak mengonsumsi fast food, restoran yang sering di kunjungi oleh anak yaitu KFC, McD, Pizza Hut , J.co, burger king dan Dunkin'Donuts. Restoran ini bukan hanya menyediakan fast food. Hal ini dikarenakan jika orang tua berbelanja kebutuhan rumah, nonton bioskop di mall, maka orang tua anak membeli makanan yang berada dekat mall, dan ada yang mengomsumsi fast food $>1$ porsi . hal ini dikarenakan anak merasa belum puas dan merasa kenyang jika hanya makan 1 porsi saja sehingga anak setiap kali makan menambah porsi makan. Sedangkan pola makan fast food jarang sebanyak 7 orang responden $(23,3 \%)$, dikarenakan anak hanya mengonsumsi $<2$ kali/minggu dengan $<1$ porsi dan bukan karena faktor anak mengonsumsi makanan fast food tetapi faktor makanan pokok seperti nasi yang mengandung karbohidrat dimana tinggi kalori dan gula yang setiap hari anak makan dari jumlah dan porsi makan $>1$ porsi.

Hasil penelitian ini, didapatkan dari data observasi yang dilakukan anak yang mengalami obesitas sebanyak 26 orang, hal ini dapat dilihat dari perhitungan antropometri IMT/U yaitu 
berat badan per tinggi badan(m), setelah itu dimasukkan dalam tabel IMT/U dan melihat tahun dan bulan menurut kemenkes jika > 2 SD, maka anak dikatakan obesitas, dan 4 orang yang mengalami overweight jika <2SD. Hasil penelitian ini sesuai dengan penelitian yang dilakukan oleh Putri et al, (2017) disimpulkan adanyanya hubungan konsumsi makanan tinggi energi (fast food) dengan kegemukan pada siswa dan siswi (Putri et al., 2017). Hal ini dikarenakan adannya kantin dilingkungan sekolah, dari hasil survey ada beberapa fast food yang dijual di kantin sekolah sebagian besar mengandung tinggi energi, lemak, dan rendah serat serta minuman tinggi gula. Sehingga kalau dikonsumsi secara berlebihan dapat meningkatkan obesitas.

Pada umumnya kandungan fast food (makanan cepat saji) memiliki karakteristik tinggi lemak, tinggi kalori, tinggi garam dan rendah serat. Hal ini berarti kandungan yang ada didalam makanan fast food memiliki kandungan lemak, tinggi kalori, tinggi garam dan rendah serat, sehingga makanan yang berada di kantin sekolah atau direstoran-restoran cepat saji memiliki kandungan yang tinggi seperti bakso memiliki kandungan tinggi karbohidrat, lemak, dan garam berarti jika di konsumsi secara berlebihan akan meningkatkan berat badan (Rendi, 2018).

Hasil penelitian ini sesuai dengan penelitian yang dilakukan oleh Junaidi, (2016), ada hubungan pola makan fast food sering dengan kejadian obesitas pada anak sekolah dasar. Hal ini diketahui bahwa murid yang konsumsi fast food nya berada pada kategori sering, mempunyai risiko lebih besar untuk mengalami obesitas, bila dibandingkan dengan murid yang tingkat konsumsi fast food nya jarang (Junaidi, 2016), hal ini dikarenakan pola makan anak yang mengonsumsi banyak yang mengandung energi dan sedikit mengandung serat. Biasanya, frekuensi anak-anak dalam konsumsi fast food rata-rata 1-2 kali seminggu, dengan jenis fast food yang sering dikonsumsi adalah fried chicken, bakso, nugget dan soft drink.

Hasil penelitian ini diperkuat dengan penelitian yang dilakukan oleh syafriani (2018) di SMK Bangkinan yang menunjukkan hubungan yang signifikan antara mengonsumsi fast food dengan overweight. Adanya hubungan tersebut sesuai dengan pendapat Soetjiningsih (2007) bahwa overweight bisa terjadi jika mengonsumsi kelebihan kalori dapat meningkatkan kelebihan berat badan. Apalagi fast food yang sudah masuk di lingkungan sekolah sehingga lebih mudah dijangkau oleh anak seperti ayam goreng sebagian besar makanan yang tersedia mengandung tinggi energi, lemak, dan rendah serat serta minuman tinggi gula anak seperti bakso dan nugget (Syafriani, 2018).

Soelistijani dan Herlianty (2003) menyatakan bahwa anak-anak yang mempunyai bakat gemuk karena faktor genetik akan cepat menjadi gemuk, apalagi jika didukung kebiasaan makan orang tua yang menyukai makanan berkalori tinggi dan anak meniru kebiasaan makan orang tuanya tersebut (Septiani \& Raharjo, 2017)

Makanan fast food atau makanan cepat saji adalah makanan yang diolah dan di sajikan dalam waktu singkat oleh penyaji makanan di rumah makan atau restoran (Purnamasari, 2017). Pada umumnya fast food (makanan cepat saji) memiliki karakteristik tinggi lemak, tinggi kalori, tinggi garam dan rendah serat. Perilaku sering mengonsumsi makanan dari luar rumah (seperti makanan dari restoran dan cepat saji) berkontribusi dalam meningkatkan berat badan anak secara berlebih (Rendi, 2018).

Salah satu faktor yang mempengaruhi tingginya prevalensi obesitas yaitu adanya perubahan gaya hidup dan pola makan. Pola makan terutama di kota besar, bergeser dari pola makan tradisional ke pola makan barat (terutama dalam bentuk fast food). Pergeseran pola makan yang komposisinya mengandung 
tinggi kalori, lemak, karbohidrat, kolesterol serta natrium, namun rendah serat seperti fast food menimbulkan ketidakseimbangan asupan gizi dan merupakan salah satu faktor risiko terhadap munculnya obesitas pada anak (Pramantara, 2015).

\section{SIMPULAN DAN SARAN}

Berdasarkan hasil penelitian ini, maka peneliti beramsumsi bahwa ada hubungan antara pola makan fast food dengan kejadian obesitas pada anak dikarenakan pola makan fast food memiliki banyak kandungan tinggi kalori seperti gula, garam dan lemak, sehingga jika di konsumsi dengan berlebihan akan mengalami peningkatan berat badan tetapi dapat dilihat dari jumlah dan jenis makanan yang dikonsumsi.

Diharapkan kepada keluarga terutama orang tua untuk memperhatikan asupan makanan pada anak, sebaiknya makanan bekal pada anak yang dimasak sendiri. untuk lebih menjaga pola makan di sekolah maupun di luar sekolah khususnya pola makan fast food agar mampu menjaga berat badan sehingga tidak terjadi obesitas.

\section{DAFTAR PUSTAKA}

Balasooriya, N. N. (2016). Impact of the Relationship between BMI and Food Intake Patterns on Obesity among Undergraduates in Sri Lanka. IOSR Journal of Nursing and Health Science, 5(3), 90-95. https://doi. org/10.9790/1959-0503069095

Effendy, S., Gunawan, M. F., Lintang, D., Argoputra, A., Dian, P., \& Abraham, Y. B. (2018). Hubungan Aktivitas Fisik Terhadap Kejadian Obesitas Berdasarkan Body Fat Percentage Di Desa Banjaroyo, Kalibawang, Kulon Progo, D.I. Yogyakarta. Jurnal Farmasi Sains Dan Komunitas, 15(1), 29-36.
Irma rachmawati, I. (2018). Faktor-faktor yang berhubungan dengan kejadian berat badan berlebih pada anak usia sekolah di MI AL-Hidayah. 17-24.

Ishak, S., Hatta, H., \& Hadi, A. J. (2019). Hubungan Pola Makan, Keterpaparan Media Dan Keturunan Terhadap Kelebihan Berat Badan Pada Siswa Sekolah Dasar. PROMOTIF: Jurnal Kesehatan Masyarakat, 9(1), 76-84.

Jeremy D. Coplan, Susan I. Wolk, Raymond R. Goetz, Neal D. Ryan, \& Ronald E. Dahl, J. John Mann, and M. M. W. (2020). Nocturnal Growth Hormone Secretion Studies in Adolescents with or without Major Depression ReExamined: Integration of Adult Clinical Follow-Up Data. Osteoarthritis and Cartilage, 28(2), 1-43. http://journals. sagepub.com/doi/10.1177/112070002 0921110\%0Ahttps://doi.org/10.1016/j. re um a.2018.06.001\%0Ahtt ps: // d o i. o r g / 10 . $1016 / \mathrm{j}$. arth.2018.03.044\%0Ahttps://reader. elsevier.com/reader/sd/pii/S1063458420 300078?token $=$ C039B8B13922A207923 0DC9AF11A333E295FCD8

Junaidi. (2016). Habist Of Consumption Fast food To Primary School Children Of Obesity In Banda Aceh. Aceh Nutrition Journal, 1(2), 78-82.

Kurdanti, W., Suryani, I., Syamsiatun, N. H., Siwi, L. P., Adityanti, M. M., Mustikaningsih, D., \& Sholihah, K. I. (2015). Faktorfaktor yang mempengaruhi kejadian obesitas pada remaja. Jurnal Gizi Klinik Indonesia, 11(4), 179. https://doi. org/10.22146/ijcn.22900

Pramantara, I. D. P. (2015). Jurnal Gizi Klinik Indonesia Konsumsi fast food dan soft drink sebagai faktor risiko obesitas pada remaja. 11(04). 
Purnamasari. (2017). Panduan Gizi \& Keseahatan Anak Sekolah (Erang Risanto (ed.); 1st ed.). Andi. https://doi.org/732-6

Putri, V. R., Angkasa, D., \& Nuzrina, R. (2017). Konsumsi Fast Food, Soft Drink, Aktivitas Fisik, dan Kejadian Overweight Siswa Sekolah Dasar di Jakarta. 48-58.

Rahmayanti, D., \& F.D., E. A. (2017). Pola Makan Anak Dengan Status Gizi Anak Usia 6-8 Tahun Di Sd Wilayah Kelurahan Cempaka. Dunia Keperawatan, 4(1), 8. https://doi.org/10.20527/dk.v4i1.2504

Rendi. (2018). Anak Obesitas Dampak Pada Kesehatan Dan Perkembangan. PT Elex Media Komputer.

Septiani, R., \& Raharjo, B. B. (2017). Pola Konsumsi Fast food, Aktivitas Fisik dan Faktor Keturunan Terhadap Kejadian obesitas (Studi Kasus pada Siswa SD Negeri 01 Tonjong Kecamatan Tonjong
Kebupaten Brebes). Public Health Perspective Journal, 2(3), 262-269.

Setyawati, V. A. V., \& Rimawati, E. (2016). Pola Konsumsi Fast food Dan Serat Sebagai Faktor Gizi Lebih Pada Remaja. Unnes Journal of Public Health, 5(3), 275. https://doi.org/10.15294/ujph.v5i3.16792 Syafriani. (2018). Hubungan Konsumsi Fast food Dan Aktifitas Fisik Dengan Kejadian Overweight Pada Siswa Di SMAN 2 Bangkinang Kota Tahun 2018. Jurnal Kesehatan Masyarakat, 2(April), 9-18.

Triana, K. Y., Lestari, N. M. P. L., Anjani, N. M. R., \& Yudiutami, N. P. P. D. (2020). Hubungan Pola Asuh Orangtua terhadap Kejadian Obesitas pada Anak Usia Sekolah. Jurnal Keperawatan Raflesia, 2(1), 31-40. https://doi.org/10.33088/jkr. v2i1.500 